\title{
Technical and economic feasibility of adding pure oxygen for rotifer production (Brachionus plicatilis) spotted snapper (Lutjanus guttatus) larvae feeding
}

Factibilidad Técnica y económica de dos sistemas de producción intensiva de rotíferos (Brachionus plicatilis) para la alimentación de larvas de pargo manchado (Lutjanus guttatus)

María del Milagro Carvajal-Oses¹, Rooel Campos-Rodríguez², Ángel Herrera-Ulloa ${ }^{3}$

Fecha de recepción: 15 de junio del 2015

Fecha de aprobación: 13 de octubre del 2015

Carvajal-Oses, M.; Campos-Rodríguez, R.; Herrera-Ullo, A. Technical and economic feasibility of adding pure oxygen for rotifer production (Brachionus plicatilis) spotted snapper (Lutjanus guttatus) larvae feeding. Tecnología en Marcha. Vol. 29, № 2, Abril-Junio 2016. Pág 14-24. 


\title{
Keywords
}

Brachionus plicatilis; Lutjanus guttatus; growth; fertility; yield; rotifers; marine culture.

\begin{abstract}
A study to technically and economically evaluate the addition of pure oxygen in a culture of rotifers for feeding marine fish in the Pacific Marine Park, Puntarenas, Costa Rica was performed. The results showed no significant differences (ANOVA $P>0.05$ ) between the cultivation with addition of oxygen treatment and control, regarding the instantaneous growth rate, crop yield, doubling time, rotifers length and maximum densities reached. Concerning the economic analysis, control culture was 53\% less expensive compared to the addition of oxygen system.
\end{abstract}

\section{Palabras clave}

Brachionus plicatilis, Lutjanus guttatus, crecimiento, fecundidad, rendimiento, rotíferos.

\section{Resumen}

Se realizó un estudio de factibilidad técnica y económica sobre la adición de oxígeno en la producción intensiva de rotíferos para alimentar peces marinos en el Parque Marino de Puntarenas Costa Rica. Los resultados mostraron que no existieron diferencias significativas $(p>0,05)$ en cuanto a la tasa instantánea de crecimiento, rendimiento del cultivo, tiempo de duplicación, longitud de los rotíferos y máximas densidades alcanzadas. Con respecto al análisis económico el sistema sin oxígeno es 53\% menos costoso que el sistema con adición de oxígeno.

\section{Introduction}

The larvae of Lutjanus guttatus as well as many marine fish are characterized by their small size, which makes them vulnerable to both rearing conditions and the quality and quantity of live food to be provided at the hatchery (Aristizábal and Suárez, 2006); this is why the first feeding is considered the bottleneck of the fish farming industry (Dhert et al., 2001). The rotifer Brachionus $\mathrm{sp}$. has been listed as one of the most important fish farming food resources (Suantika et al., 2001), by size (Hagiwara et al., 2007), swimming speed and his ability to remain suspended in the water column (Fielder et al., 2000), so it is necessary to establish a massive stable supply enabling mass production of these larvae for consumption in the laboratory (Dhert et al., 2001).

This has encouraged to research on the conditions that optimize the growth of populations of this organism (Kostopoulou et al., 2006; Sayegh et al., 2007; Papakostas et al., 2007; Kobayashi et al., 2008; Larsen et al., 2008; Yin and Zhao, 2008; Cavalin and Weirich, 2009; Mahmoudzadeh et al., 2009; Qi et al., 2009), specifically, may studies related to the addition of pure oxygen as support for rotifer cultures (Yoshimura et al., 1996; Dhert et al., 2001; Yoshimura et al., 2003), however, is necessary to evaluate the economic conditions as well as staff availability and infrastructure before deciding the technique with which to work, as noted by Suantika et al. (2003) in their study on rotifers production progress.

The aim of this study was to optimize the production of rotifers Brachionus plicatilis according to economic and technical conditions developed at the Pacific Marine Park and improve his technology on marine-culture in Costa Rica. 


\section{Materials and methods}

An own strain of Brachionus plicatilis from the Pacific Marine Park stock was used, which is located in the city of Puntarenas $\left(9,97^{\circ} \mathrm{N} 84,82^{\circ} \mathrm{W}\right)$, Costa Rica at an altitude of 0 meters above the sea level. The experiment consisted of three replicates both to evaluate the population growth curve in the system with addition of pure oxygen and the control treatment (no addition of pure oxygen). The first test, ha both oxygen added as 99\% and oxygen by an electric aeration blower driven, control culture only had air pushed by the blower. To conduct the experiment transparent fiberglass tanks of 500 liters in volume were used, located under covered roof of transparent polycarbonate sheets with an entry of light during day hours (5000 lux). Cultures were initiated with a density of 200 rotifer. $\mathrm{ml}^{-1}$.

\section{Water quality}

To maintain the quality of seawater, ultraviolet rays were irradiated filtered to $1 \mu \mathrm{m}$. To collect flocs of organic matter, suspended absorbent fabrics were installed in tanks of $2 \times 0.2 \mathrm{~m}$ and a skimmer was installed to collect organic remains. The bottom of the tanks were cleared to maintain the cleanliness of the crop and finally $0.75 \mathrm{~g}$. day of probiotic Epicin pond were added to the tanks (Bionetworks Epicor Inc., Eastampton, NJ 08060).

\section{Feeding}

The daily maintenance diet was based on dry yeast (Saccharomyces cerevisiae) and addition of micro-algae Nannochloropsis oculata achieving the recommended density in the tank by Dhert et al. (2001) with 200,000 cells . $\mathrm{ml}^{-1}$. Regarding the amount of yeast used, the amount was based on the formula of Suantika et al. (2000), which corresponds to:

$$
\text { CHS }=0,035 D^{0,415} \mathrm{~V}
$$

where:

$\mathrm{CHS}=$ weight of food $(\mathrm{g})$

$\mathrm{D}=$ density of rotifers $\mathrm{ml}^{-1}$

$\mathrm{V}=$ volume $(\mathrm{I})$

The way to deliver yeast to rotifers was based on Benetti et al., (2008), which consists on preparing them in coolers of 20 liters each with constant aeration, decreasing the temperature with ice down to $10^{\circ} \mathrm{C}$, adding $1.25 \mathrm{~g}$ of probiotic Epicin ponds and finally deliver this to rotifers by continuous drip for 24 hours using a peristaltic pump of Chem Feed $®$ brand (Blue-White Industries, Huntington Beach, California 92649).

\section{Physicochemical parameters}

The oxygen dewar was regulated to keep on the rotifer cultures an oscillating oxygen interval between 5 and $6 \mathrm{mg} . \mathrm{I}^{-1}$. The temperature and dissolved oxygen (DO) was registered three times a day with a YSI oxygen meter model 550A. Cultures were maintained in a salinity range between 20 and 22 ppt. In addition the $\mathrm{pH}$ and the concentration of ammonia (NH3/ NH4 ${ }^{+}$) were recorded daily using a colorimetric test Aquarium Pharmaceuticals (Fishcare North America, Inc. Hamilton, California, PA 18914).

\section{Population parameters}

Density (ind . $\mathrm{ml}^{-1}$ ) and fecundity (eggs . rot $^{-1}$ ) of Brachionus plicatilis, was calculated base on ten counts daily ( $1 \mathrm{ml}$ aliquots) of live rotifers using a stereoscope "Optimum model ZM-160 AT". Also when the cultures showed their highest population density values calculation of the 
instantaneous growth rate (day ${ }^{-1}$ ), doubling time (day ${ }^{-1}$ ) and crop yield (rot . $\mathrm{l}^{-1}$. day ${ }^{-1}$ ) were performed, which are given by the following formulas:

Instantaneous growth rate (Suantika et al., 2003):

$$
K=\frac{\operatorname{Ln} N_{f}-\operatorname{Ln} N_{o}}{t}
$$

Doubling time (Vallejo et al., 1993):

$$
t d=\frac{\operatorname{Ln} 2}{K}
$$

Crop yield (Vallejo et al., 1993):

$$
r=\frac{N_{f}-N_{o}}{t}
$$

where:

$\mathrm{N}_{\mathrm{f}}=$ final number of ind $\cdot \mathrm{ml}^{-1}$

$\mathrm{N}_{\mathrm{o}}=$ initial number of ind $\cdot \mathrm{ml}^{-1}$

$\mathrm{t}=$ time in days.

Length and lorica width (microns)

Five daily rotifers were taken randomly from each tank to measure with the microscope (H-903 model Optima) both the length and lorica width (body wall). Immobilization was obtain by using lugol reagent.

\section{Economic Analysis}

Concerning economic analysis, the items of consumption that comprise production costs for 2,000 million rotifers (oxygen treatment and control) were defined, these were: power consumption, oxygen, algae, yeast, probiotic and labor. As a final activity, the percentage of total feed costs for a pond of 4 tons was calculated; based on the methodology of Boza et al., 2008 which used a spawning of 50,000 and getting at day 67 after hatching a survival of 1.5\%

of Lutjanus guttatus larvae which implies: the use of rotifers, Artemia cysts, algae and Otohime as formulated feed (Reed Mariculture, Inc. Hamilton Ave, Suite 100 Campbell, CA 95008).

\section{Statistical Analysis}

For statistical analysis of each result, the normal distribution of the data was initially verified (Shapiro-Wilks test) as well as determination of the homogeneity of variance (Levene test), followed by an analysis of variance (ANOVA) using the software Infostat.

\section{Results}

\section{Physico-chemical conditions}

It was observed that in oxygen system, the DO was maintained at an average range from $6.47 \pm 0.37$ and $4.62 \pm 0.68 \mathrm{mg} \cdot \mathrm{I}^{-1}$ throughout the culture time, while in the control treatment values declined $5.52 \pm 0.88$ to $0.99 \pm 0.52 \mathrm{mg} . \mathrm{l}^{-1}$ at the last day of culture, showing significant differences from the second day (ANOVA P <0.05) between treatments. The $\mathrm{pH}$ was stable in both cultives 
without significant variations (ANOVA P > 0.05) throughout the investigation, with values between $7.46 \pm 0.10$ and $7.5 \pm 0.20 \mathrm{mg} \cdot \mathrm{l}^{-1}$. The $\mathrm{NH} 3 / \mathrm{NH}^{+}$showed an increase without significant changes between the two systems (ANOVA P>0.05), reaching values up to $8 \pm 0.1 \mathrm{mg} \cdot \mathrm{l}^{-1}$ on the last day of treatment with a temperature fluctuation between $29.50 \pm 0.20$ and $26.58 \pm 0.63^{\circ} \mathrm{C}$ showing no significant variation (ANOVA P> 0.05).

\section{Population parameters}

As for the maximum reported densities of rot . Ind ${ }^{-1}$, there were no significant differences (ANOVA $P>0.05$ ) with the oxygen system treatment having $750 \pm 60$ rot . ind $^{-1}$ and control $825 \pm 33$ rot . ind $^{-}$ ${ }^{1}$. The culture declined to provide oxygen from seventh day treatment and control from the third day (Fig. 1), with significance shown for the duration of the culture (ANOVA $P<0.05$ ). In general a total of $55 \times 10^{7}$ rotifers were obtained in both systems.
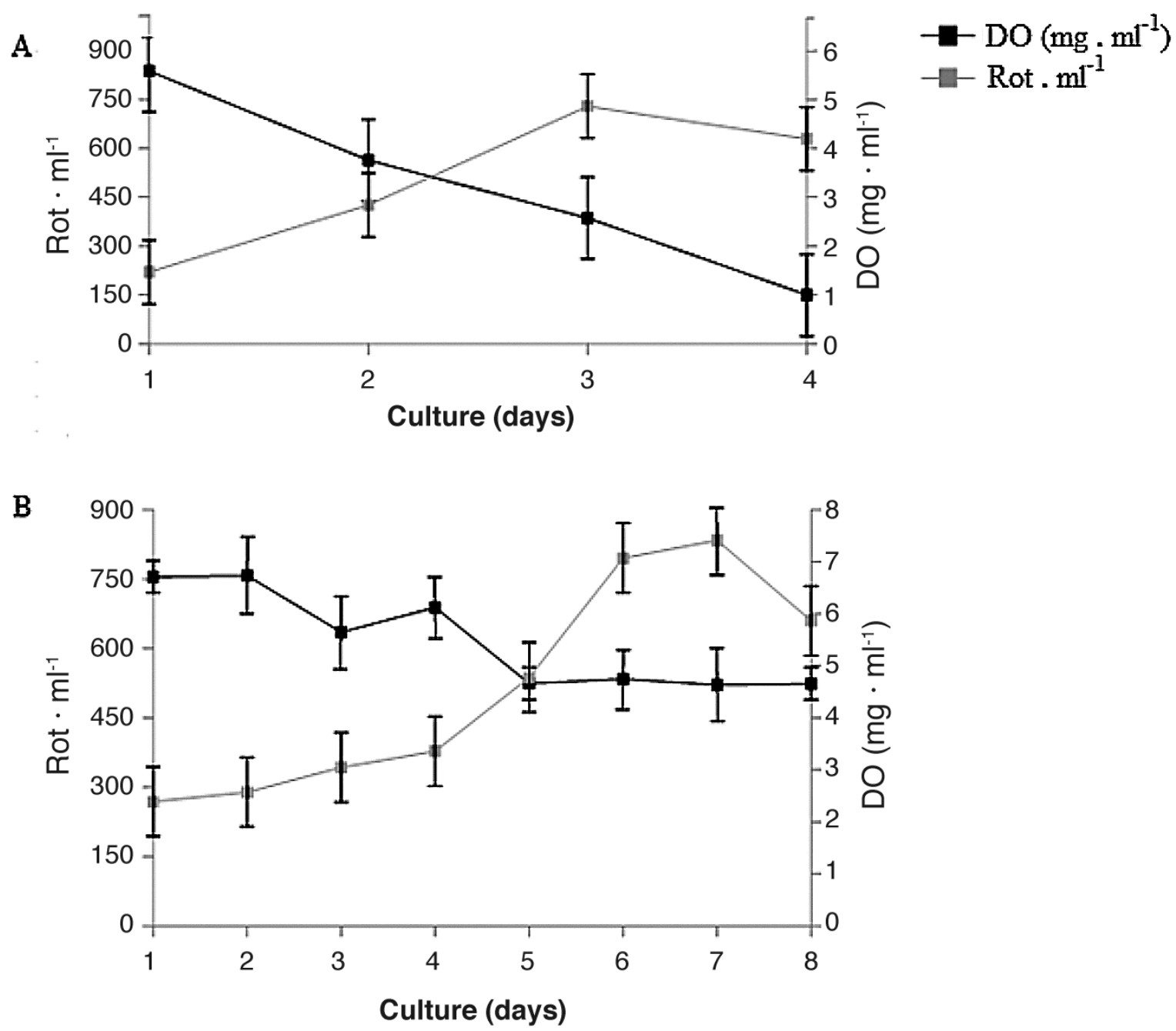

Figure 1. Density of rot $\cdot \mathrm{ml}^{-1}$ and $\mathrm{DO}\left(\mathrm{mg} \cdot \mathrm{I}^{-1}\right)$ in the control culture $(\mathrm{A})$ and with addition of oxygen (B).

The instantaneous growth rate, doubling time and crop yield did not differ significantly between treatments (Table 1) (ANOVA P> 0.05). 
Table 1. ANOVA of instantaneous growth rate $\left(\right.$ day $\left.^{-1}\right)$, doubling time $\left(\right.$ day $\left.^{-1}\right)$ and population performance (rot . $^{-1}$. day 1) (mean values \pm standard deviation) in both rotifer production systems.

\begin{tabular}{|c|c|c|c|}
\hline \multirow{2}{*}{ Variable } & \multicolumn{2}{|c|}{ Treatment } & \multirow{2}{*}{ P } \\
\cline { 2 - 3 } & Oxigen & Without oxigen & \\
\hline Instantaneous growth rate. & $0,212 \pm 0,04$ & $0,35 \pm 0,08$ & 0,056 \\
\hline Doubling time & $3,35 \pm 0,73$ & $2,011 \pm 0,43$ & 0,053 \\
\hline Culture yield & $98.140 \pm 25,96$ & $167.850 \pm 36,85$ & 0,055 \\
\hline
\end{tabular}

The fecundity (F) obtained from day 1 to 4 in both cultures showed statistical differences (ANOVA $P<0.05)$, reporting for the control system the highest average for day two, and in the culture with oxygen the highest average were obtained for the remaining three days. All F exceeded 0.15 rot . $\left.\right|^{-1}$. day ${ }^{-1}$. The lowest fecundity were reported for the last days of the period of both cultures (Fig. 2).

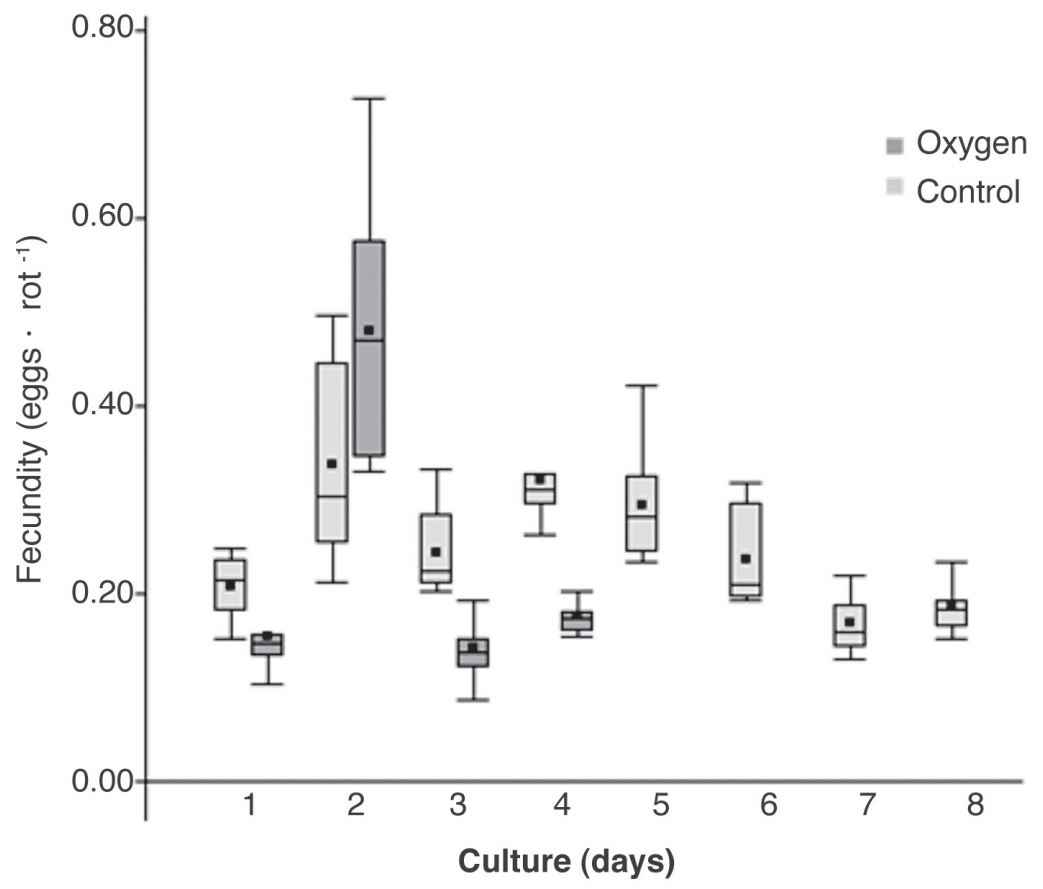

Figure 2. Fecundity (mean values \pm standard deviation) (eggs $\cdot$ rot $^{-1}$ ) obtained in Brachionus plicatilis cultures with and without oxygen supply.

\section{Length and width of lorica}

There were no significant differences (ANOVA p> 0.05) between the means of morphometric characteristics of both rotifers systems; the oxygen system presented an average length of $150,02 \pm 11,92$ and a width of $114,10 \pm 11,92 \mu \mathrm{m}$, while in the control treatment a length of $147,82 \pm 11,86$ and a width $111,3 \pm 11,18 \mu \mathrm{m}$. 


\section{Economic Analysis}

It is $53 \%$ less expensive to produce rotifers without oxygen supply in the Pacific Marine Park. The $47 \%$ of total costs in the system with oxygen was used to purchase oxygen while $57 \%$ of capital invested in the control treatment was assigned to labor. In addition, a million rotifers in the culture with addition of oxygen would cost approximately $\$ 1,06 \pm 0,17$ and in the system without oxygen addition $\$ 0,53 \pm 0,04$; there is statistically significant difference between the price of a million rotifers in both systems (ANOVA P>0.05). Table 2 shows an idea of the total costs required to develop a batch system for a month using oxygen and without oxygen in the Pacific Marine Park.

Table 2. Breakdown of Costs $(\$)$ used in the production of rotifers.

\begin{tabular}{|c|c|c|c|}
\hline \multicolumn{4}{|c|}{ Same costs for both rotifer production systems } \\
\hline \multirow{2}{*}{ Wage } & \multirow{2}{*}{ Hour cost $(\$)$} & Amount & \multirow{2}{*}{ Total $(\$)$} \\
\hline & & (hours) & \\
\hline Biologist & 6,0 & 96,0 & 576,0 \\
\hline Assistant & 3,5 & 16,0 & 56,2 \\
\hline Statutory benefits & $\begin{array}{c}\text { Employer } \\
\text { contribution (\%) }\end{array}$ & & Total $(\$)$ \\
\hline Social chargues & 36,5 & & 230,7 \\
\hline \multirow[t]{2}{*}{ Power Consumption } & Cost KWh (\$) & Energy (KWh) & Total $(\$)$ \\
\hline & 0,2 & & \\
\hline Air conditioning & & 61,0 & 9,3 \\
\hline Algal incubator & & 332,0 & 50,5 \\
\hline Autoclave & & 172,0 & 26,2 \\
\hline Blower & & 158,0 & 24,0 \\
\hline Microscope & & 6,5 & 1,0 \\
\hline Peristaltic pumps & & 5,4 & 0,8 \\
\hline Pumps & & 8,4 & 2,5 \\
\hline Seawater pump & & 8,4 & 1,3 \\
\hline Semi analytical balance & & 8,0 & 1,4 \\
\hline Stereoscope & & 13,5 & 2,0 \\
\hline Ultraviolet lamps & & 202,0 & 30,7 \\
\hline TOTAL & & & 149,6 \\
\hline Reagents & Cost per gram (\$) & Quantity (g) & Total $(\$)$ \\
\hline Ammonium chloride & 0,1 & 54,0 & 5,4 \\
\hline EDTA & 0,1 & 8,2 & 0,5 \\
\hline Ferric chloride & 0,1 & 8,7 & 0,5 \\
\hline lodine & 0,1 & 10,0 & 0,8 \\
\hline Potassium iodide & 0,6 & 154,0 & 24,0 \\
\hline Sodium nitrate & 0,4 & 2,0 & 0,8 \\
\hline Sodium phosphate & 0,1 & 15,0 & 1,0 \\
\hline Vitamins & 0,0 & 30,0 & 0,3 \\
\hline
\end{tabular}




\begin{tabular}{|c|c|c|c|}
\hline \multicolumn{4}{|c|}{ Other specific costs for each system } \\
\hline Oxygen System & Unit Cost $(\$)$ & Amount & Total $(\$)$ \\
\hline Oxygen & 500,0 & 2 dewar & $1.000,0$ \\
\hline Probiotic & 1,0 & 23 pills & 23,0 \\
\hline Yeast & 3,8 & 13 packages & 49,4 \\
\hline System without oxygen & & & \\
\hline Probiotic & 1,0 & 23 pills & 23,0 \\
\hline Yeast & 3,8 & 15 packages & 57,0 \\
\hline TOTAL OXYGEN SYSTEM & & & 2120,0 \\
\hline TOTAL SYSTEM WITHOUT OXYGEN & & & 1125,8 \\
\hline
\end{tabular}

It takes \$ 2089 to feed a tank with larvae using oxygen fed produced rotifers (total cost: $70 \%$ corresponded to rotifers, $22 \%$ in microalgae, $6 \%$ for shrimp and $1.5 \%$ in otohime) and $\$ 1193$ with rotifers from cultures without oxygen supply (49\% rotifers, 38\% microalgae 10\% brine and $2.5 \%$ otohime). According to these costs, a spotted snapper larvae fed with rotifers from oxygen supplied systems would cost \$ 0.27 and a larva using the rotifer production control system would have an economic value of $\$ 0.16$.

\section{Discussion}

Although the oxygen supply system sustain concentrations within the recommended by Orhum and Benetti (2001), it always declined at the population level due to the high reported values of ammonium (Yoshimura et al., 2003). The control treatment exemplified the two greatest constraints to the development of cultures exposed by Yoshimura et al. (2003) corresponding to the low concentration of DO $\left(>1 \mathrm{mg} \cdot \mathrm{l}^{-1}\right)($ fig. 1$)$ and high values of ionized ammonia, thus also its short duration of $4 \pm 1$ days. High concentrations of nitrogen compounds can be controlled with water exchange (Orhum and Benetti, 2001) or with water recirculation systems using biofilters and ozone (Bentley, 2008). The temperatures reported in this paper are considered common to the Gulf of Nicoya (Vega 2010), and are within the recommended Orhum and Benetti (2001), who suggest that temperatures in rotifer cultures must not exceed $30^{\circ} \mathrm{C}$ range since it affects the levels of $\mathrm{DO}$ and reproductive capacity of organisms. As for $\mathrm{pH}$, eventhough these organisms can survive within wide ranges (Yin and Niu, 2008), Fielder et al., (2000) recommends a range between 7.4 and 8.2, which agrees with the values obtained in this work.

Regarding the highest population densities obtained on both systems (> $600 \mathrm{rot} \cdot \mathrm{ml}^{-1}$ ), these are considered common for tanks from 500 to $1000 \mathrm{~L}$ in batch rotifer production centers (Dhert et al., 2001). In terms of population parameters (Table 1), both growth rates are considered typical within the stated range for B. plicatilis in batch cultures (Suantika et al., 2003, Tinh et al., 2006). The doubling times of both systems match the reported ( 2 to 3.3 day $^{-1}$ ) range by Vallejo et al., (1993) in his study of B. plicatilis. Population yields of both crops are considered high compared to that reported by Abu-Rezq and James (2005) of $12.130 \pm 1,89 \mathrm{rot} \cdot \mathrm{l}^{-1} \cdot \mathrm{day}^{-1}$ and that of Cisneros (2011) ranging from $1.330 \pm 0,33$ a $13.580 \pm 0,02$ rot $\cdot l^{-1} \cdot$ day $^{-1}$. The yields of rotifers improve the more HUFA's and proteins their feeds contain (Dhert et al., 2001; Cisneros, 2011), adding to the success of using microalgae on such cultures (Suantika et al, 2003, Aragão et al., 2004, Benetti et al., 2008, Ferreira et al., 2008).

The fecundity obtained in this work are considered most suitable $(<0.2)$ to maintain stable crops (Orhum and Benetti, 2001), however these forms decreased with increasing days in culture due 
to deterioration of the quality of water (Hagiwara et al., 2007). Regarding the size of the rotifer, this must be consistent with the mouth opening of the larvae which is being grown (Hagiwara et al., 2001). An amount of $50 \%$ of the lengths of the rotifers reported in this paper are on the size limit recommended by Boza et al., (2008), indicating that for the production of Lutjanus guttatus the zooplankton to be used must be than 150 microns in length. In addition, the sizes of rotifers of both systems coincide with the results obtained by Hagiwara (2001), the author reports that the size of the species Brachionus sp. are within a range of 90 and $340 \mu \mathrm{m}$. As there is no statistical differences between the morphometric characteristics in both crops it can be said that oxygen is not a variable that influences this aspect, the above is further supported by Hagiwara et al., (2007) where it is mentioned that the size of rotifers can be modified by sudden changes in temperature, salinity or with different food regime.

From an economic standpoint, the non-use of oxygen brings more economic benefits to Pacific Marine Park since to produce 2,000 million rotifers day ${ }^{-1}$, and costs are $60 \%$ cheaper than with oxygen supply. The reported cost for a million of rotifers in this study was higher than those published by Bentley et al., (2008)(\$0.009) and Suantika et al., (2003) (\$0.048), however, it was lower than Alvarez-Lajonchere and Álvarez et.al, (2013) at a cost of $\$ 1.65$ in batch cultures. Oxygen is used by many authors as a resource to support the stability of rotifer cultures (Kostopoulou et al., 2006; Sayegh et al., 2007; Papakostas et al., 2007; Kobayashi et al ., 2008; Larsen et al. 2008; Yin and Zhao, 2008; Cavalin and Weirich, 2009; Mahmoudzadeh et a.l, 2009; Qi et al, 2009), however, in the Pacific Marine Park adding oxygen posed no technical difference (ANOVA p > 0.05) compared to control culture due to several factors; the first is related to the fact that dissolved oxygen was controlled only during the day (it was not mechanized and there were workers who labored night shift) which did not allow a good control of this variable. According to Alvarez-Lajonchere and Álvarez et.al, (2013) results in rotifer cultures depend on the correct technology developed in the laboratory. Additionally, high temperatures (Yin and Zhao, 2008) and proper nutrition (Dhert et al., 2002; Cabrera, 2008; Cisneros, 2011;. Rojo-Cebrero et al, 2012) allowed the control culture to achieve similar densities (ANOVA p>0.05) that that of the oxygen added culture. In conclusion for the Pacific Marine Park is technically and economically more feasible the non-application of pure oxygen to rotifer cultures as long as it provides daily refills seawater to its support systems (Orhum and Benetti, 2001) to avoid early falls through ionized ammonia accumulation (Yoshimura et al., 2003).

\section{Acknowledgements}

The authors thank the Production Module Pacific Marine Park for the facilities provided to conduct this work.

\section{References}

Abu-Rezq, T.,\& James , C. (2005). Application of probiotics in rotifer production systems for marine fish hatcheries. Marine finfish Aquaculture, 10 (3), 27-29.

Alvarez-Lajonchére, L.,\&Sánchez-Téllez, J. (2013). Análisis financiero de una producción piloto del rotífero Brachionus rotundiformis, con una dieta artificial. Rev.Invest.Mar, 33(2),28-36.

Aragão, C., Conceição, L., Dinis, M., \&Fihn, H. ( 2004). Amino acid pools of rotifers and Artemia under different conditions: nutritional implications for fish larvae.Aquaculture, 234, 429-445.

Aristizábal, E., \&Suárez, J. (2006). Efficiency of co-feeding red porgy (Pagrus pagrus L.) larvae with live and compound diet. Revista de Biología Marina y Oceanografía, 41(2), 203 - 208.

Benetti, D., Sardenberg, B., Welch, A., Hoenig, R., Orhun, R., \&Zink, I. (2008). Intensive larval husbandry and fingerling production of cobia Rachycentron canadum. Aquaculture, 281, 22-27. 
Bentley, C., Carrol, P.,\& Watanabe, W. (2008). Intensive rotifer production in a pilot scale continuous culture recirculating system using non viable microalgae and a ammonia neutralizer. Journal of the World Aquaculture society, 39 (5),625-635.

Boza, J., Calvo, E., Solís, N.,\&Komen, L. ( 2008). Desove inducido y crecimiento larval del pargo manchado, Lutjanus guttatus, en la estación de Biología Marina de Puntarenas, Costa Rica. Ciencias Marinas, 34 (2), 239-252.

Cabrera, F. (2008). Tasa de crecimiento poblacional del rotífero Brachionus rotundiformis (Rotifera: Brachionidae) en un quimiostato de dos cámaras. Revista de Biología Tropical, 56 (3),1149-1157.

Cavalin, F., \& Weirich, C. (2009). Larval performance of aquacultured Florida pompano (Trachinotus carolinus) fed rotifers (Brachionus plicatilis) enriched with selected commercial diets. Aquaculture, 292,67-73.

Cisneros, R. (2011). Rendimiento poblacional del rotífero nativo Brachionus sp. "Cayman" utilizando diferentes enriquecedores. Ecología aplicada, 10(2),99-105.

Dhert, P., Rombaut, G., Suantika, G., \& Sorgeloos, P. (2001). Advancement of rotifer culture and manipulation techniques in Europe.Aquaculture, 200,129-146.

Ferreira, M., Fábregas, J.,\& Otero, A. (2008).Enriching rotifers with "premium" microalgae. Isochrysis aff. Galbana clone T-ISO. Aquaculture, 279, 126-130.

Fielder, D., Purser, G.,y Battlaglene, S. (2000). Effect of rapid changes in temperature and salinity on availability of the rotifers Brachionus rotundiformis and Brachionus plicatilis. Aquaculture, 189, 85-99.

Hagiwara, A., Gallardo W., Assavaaree ,M., Kotani, T.,\& de Araujo, A. (2001). Live food production in Japan: recent progress and future aspects. Aquaculture, 200, 111-127.

Hagiwara, A., Suga, K., Akazawa, A., \& Sakakura, Y. (2007). Development of rotifer strains with useful traits for rearing fish larvae. Aquaculture, 268, 44-52.

Kobayashi, T., Nagase, T., Hino, A.,\&Takeuchi, T. (2008). Effect of combination feeding of Nannochloropsis and freshwater Chlorella on the fatty acid composition of rotifer Brachionus plicatilis in a continuous culture. Fisheries Science, 74,649-656.

Kostopoulou, V., Miliou, H., Katis, G.,\& Verriopoulos, G. (2006). Changes in the population structure of the lineage 'Nevada' belonging to the Brachionus plicatilis species complex, batch-cultured under different feeding regimes.Aquacult Int., 14,451-466.

Larsen, P., Madsen, C.,\& Ulrik, H. ( 2008). Effect of temperature and viscosity on swimming velocity of the copepod Acartia tonsa, brine shrimp Artemia salina and rotifer Brachionus plicatilis. Aquatic Biology, 4,47-54.

Mahmoudzadeh, H., Ahmadi, H.,\& Shamsaei, M. (2009). Comparison of rotifer Brachionus plicatilis as a choice of live feed dry feed in rearing Coregonus lavaretus fry. Aquaculture Nutrition, 15,129-134.

Orhum, M., \&Benetti, D. (2001). Rotifer management in marine fish culture. GAA ADV, 4(3),49-50.

Papakostas, S., De Wolf, T., Triantafyllidis, A., Vasileiadou, K., Kanellis, D., Cecconi, P., Kappas, I., \&Abatzopoulos, T. (2007). Follow-up of hatchery rotifer cultures with regard to their genetic identity. Journal of Biological Research, 7,41-49.

Qi, Z., Dierckens, K., Defoirdt, T., Sorgeloos, P., Boom, N., Bao, Z.,\& Bossier, P. (2009). Effects of feeding regime and probionts on the diverting microbial communities in rotifer Brachionus culture. Aquacult Int., 17,303-315.

Rojo- Cebrero, A., Román-Reyes, J., Rodríguez-Montes de Oca, G., Nieves-Soto, M., Piña-Valdez, P.,\& Medina-Jasso, M. (2012). Balance energético del rotífero Brachionus rotundiformis Tschugunoff 1921, alimentado con cuatro especies de microalgas. Universidad y Ciencia, 28(3), 231-244.

Sayegh, F., Radi, N., \&Montagnes, D. (2007). Do strain differences in microalgae alter their relative quality as a food for the rotifer Brachionus plicatilis? Aquaculture, 273, 665-678.

Suantika, G., Dher,t P., Murhudah, M.,\& Sorgeloos, P. (2000). High-density production of the rotifer Brachionus plicatilis in a recirculation system: consideration of water quality, zootechnical and nutritional aspects. Aquacultural engineering, 21 (3),201-214.

Suantika, G., Dhert, P., Rombaut, G., Vandenbergue, J., De Wolf, T.,\& Sorgeloos, P. (2001). The use of ozone in a high density recirculation system for rotifers. Aquaculture, 201,35-49.

Suantika, G., Dhert, P., Sweetman, E., O' Brien, E., \&Sorgeloos, P. (2003). Technical and economical feasibility of a rotifer recirculation system. Aquaculture, 227,173-189. 
Tinh, N., Phuoc, N., Dierckens, K., Sorgeloos, P., \& Bossier, P. (2006). Gnotobiotically grown rotifer Brachionus plicatilis sensu strictu as a tool for evaluation of microbial functions and nutritional value of different food types. Aquaculture, 253, 421- 432.

Vallejo, A., Newmark, F., \&Criales, M.(1993). Efecto de la salinidad sobre el crecimiento poblacional y rendimiento del rotífero Brachionus plicatilis (cepa Ciénaga Grande de Santa Marta).Boletín de Investigaciones marinas y Costeras, 22,112-121.

Vega, L. (2010). Evaluación poblacional del stock explotable del complejo Ophistonema (pisces: Clupeidae) en el Golfo de Nicoya, Costa Rica. Rev .Mar. Cost., 2,83-94.

Yin, W., \&Niu, J. (2008). Effect of pH on survival, reproduction, egg viability and growth rate of five closely related rotifer species. Aquat Ecol.,42, 607-616.

Yin, W.,\& Zhao, W. (2008). Studies on life history characteristics of Brachionus plicatilis O. F. Müller (Rotifera) in relation to temperature, salinity and food algae. Aquat. Ecol.,42,165-176.

Yoshimura, K., Hagiwara, A., Yoshimatsu, T.,\& Kitajima, C. (1996). Culture technology of marine rotifers and the implications of marine fish in Japan. Mar.Fresh.Res., 47,217-222.

Yoshimura, K., Tanaka, K., \&Yoshimatsu, T. ( 2003). A novel culture system for the ultra-high-density production of the rotifer, Brachionus rotundiformis a preliminary report. Aquaculture, 227, 165-172. 